\title{
The Ordinary Quality of Resistance: From Milgram's Laboratory to the Village of Le Chambon
}

\author{
François Rochat and Andre Modigliani
}

The Universin of Michigan

According to Hannah Arendt's banality of evil thesis, endorsed by Milgram, it is possible for ordinary people to perform horrendous deeds when these are rendered routine and morally neutral through a framework of legitimate authority. But such a view of human capacities does nothing to explain the actions of equally ordinary people who defied authorities to rescue potential victims during the Holocaust. This article formulates a contrasting but noncontradictory conception-the ordinariness of goodness-and illustrates it by examining closely how the people of the French village of Le Chambon managed, during World War $I I$, to resist the efforts of Vichy authorities to induce them to participate in the persecution of minority peoples, thereby enabling them to save thousands of refugees. Notable features of their resistance are then compared to the ordinary behavior of some of Milgram's disobedient subjects.

\section{Introduction}

During World War I], those who participated in the persecutions of minority peoples rarely initiated the harming of other human beings, but they did inflict harm by going along with the orders of authorities. Persecutors were sometimes very zealous, even vicious, in carrying out the orders they were given, yet they almost always occupied subordinate positions, following orders or behaving in accord with the inducements of authorities. Does such behavior imply there is

This research was supported by Grant No. 810-033302 from the Swiss National Science Foundation to François Rochat.

Correspondence regarding this article should be directed to François Rochat, Rue du Cret 4B. CH-1006 Lausanne, Switzerland. 
something in the nature of authority-subordinate relationships that renders subordinate actors capable of complying with even the most horrendous of orders?

Milgram's (1974) study of obedience to authority-with its 24 different experimental conditions-was an outstanding attempt to deal with this difficult question. When Milgram began his experiments, he did not expect his subjects to be so easily induced to give electric shocks to a man introduced to them as a fellow subject in the experiment, whom they believed was selected at random to be the "learner" in a so-called Memory and Learning Project. But in fact, most subjects did comply with the experimenter as he persistently pressed them to administer even stronger electric shocks - this despite the learner's protests and his pleas to be released from the experiment. As the procedure progressed, the learner became a victim of the Memory and Learning Project.

Milgram's subjects did not know that the learner was actually a confederate of the experimenter. The entire procedure had been designed to trap the subject between the experimenter's firm prods to continue and the learner's desperate pleas to be released. What stunned Milgram-and still astounds people who learn about his experiments - is the proportion of subjects who ended up being completely obedient, inflicting a shock of 450 volts despite the fact that the learner gave no further responses after receiving 330 volts, to which he had reacted with an agonized scream followed by hysterical pleas to be set free.

Milgram conducted his experiments in New Haven, between 1960 and 1962, with the Holocaust clearly in mind (see Alexandra Milgram's testimony in Humer, 1994). He believed his findings were quite consistent with Hannah Arend's formulation of the banality of evil-a conception of the obedience process that she first developed in 1961, while covering Adolph Eichmann's war crimes trial in Jerusalem, as a reporter for The New Yorker (Arendt, 1963; Milgram, 1974; Blass, 1993; Katz, 1993; Miller, this issue). The banality of evil is often used to understand destructive obedience both in Milgram's findings and in historical data on the Holocaust (e.g.. Fein, 1979; Bauman, 1991; Browning, 1992). It is also a common lesson that authors deduce from Milgram's obedience experiment-a lesson upon which Darley reflects in a very interesting way:

One way of wording the insight that arises from these considerations such as have been examined here, is that it is generally possible for a person to do evil when that evil has been "banalized"-rendered routine and morally neutral To analyze these processes in order to better understand them, we give phenomenological accounts of how ordinary people neutralize evil as they are caught up by forces urging them to commit it. By doing this, do we banalize evil at second hand, as we render it understandable, and nake its commission easier? (Darley, 1992, p. 218)

In other words, Darley's important question suggests that our manner of teaching and writing about the banality of evil can make evil look natural and almost inevitable under certain conditions.

Milgram's findings do in fact allow us to conclude that doing evil is quite a 
likely outcome of authority-subordinate relationships, and that many ordinary men and women will hurt innocent victims simply because they have been ordered to do so by an experimenter conducting a research project on memory and learning. From Arendt's report on Eichmann's behavior during the Nazi era in Europe and during his trial in Jerusalem, we can conclude that doing evil can indeed be a routine job, executed without hatred or strong feelings, in a neutral and administrative manner. Yet we know that there are men and women who did not go along with the systematic persecutions conducted by the Third Reich and its allies, and who, instead, defied authorities' orders and helped the targeted peoples. We also know (e.g., Fogelman, 1987, 1994; Oliner \& Oliner, 1988; Stein, 1988; Tec, 1986) that many of these helpers were quite ordinary, possessing no distinctive demographic or personality characteristics nor socializing experiences (Gushee, 1993). When these ordinary people are later pressed to explain what gave them the strength to resist such powerful authorities, they often respond that they were merely helping people whom they felt they could assist (c.g. Block \& Drucker, 1992; Keller. 1993; Sauvage, 1988). If their answers are accurate. we must confront the possibility that goodness, too, may be far more ordinary than we assume it to be. Perhaps we are wrong in our propensity to believe goodness is the province of heroes and saints-and by extension, to assume that only extraordinary persons are capable of opposing malevolent orders issued by powerful authorities. As one helper stated in response to a question about the moral qualities of the many rescuers in his village,

It doesn't mean that in our village there were no people with faults and failings, it s a communauté like any other communauté, and I think that means that any communauté. anywhere, has a choice tu make, and can choose right, so that even people who may seem very ordinary can do great things if they have the opportunity. (Lesley Maber in Sauvage, 1988)

This is exactly what our own studies of resistance to authority scem to indicate: Those who refused to obey the orders of authorities, and came to the aid of persecuted people, were neither saints nor heroes. Rather, their goodness was that of ordinary men and women who were responsive to the victims' manifest need for help. The way they acted was part of their everyday life, and they did not perceive it as something extraordinary. They did not fecl like heroes at the time, nor do they want to be seen as such in retrospect.

Gur observations confirm one of the most salient features of the accounts of rescuers' actions during the Nazi era in Europe: Helping happened progressively and was seldom premeditated. At first, it was merely a matter of performing small, modest actions. Then, gradually, as the helpers became more involved in what they were doing, these initial modest steps evolved into more major, organized undertakings that made it possible to save large numbers of people from arrest, deportation, and murder. In retrospect, their course of action was indeed outstanding. Yet it all started with people helping as a matter of course, almost by 
accident, doing small things out of common civility. Only eventually did it turn out to be a highly effective way of saving many human lives. Our understanding of rescuers' courses of action as an unfolding process, not only explains why being viewed as heroes continues to make no sense to them, but it also illustrates that goodness is not something extraordinary. Thus, the banalization of evil, as explained by Arendt and demonstrated by Milgram, is not an inevitable outcome of processes unleashed when powerful authorities give harmful orders to subordinates. Yes, the chances that evil will be perpetrated are increased when it is rendered banal, but goodness does not disappear in the process of making evil commonplace. And this holds true for Milgram's experiments as well. Clearly, not all of his subjects complied with the experimenter's orders. Indeed, in his best known experimental condition (depicted in his film Obedience, 1965), more than one-third of all subjects refused to continue hurting the victim.

In order to gain a better understanding of resistance, we collected data both on the behavior of rescuers' during the Holocaust and on the behavior of disobedient subjects' in Milgram's experiment. With respect to rescuers, we found that those who aided persecuted people acted in ways best conceptualized in terms of the ordinariness of goodness. In the pages that follow, we try to demonstrate that the ordinariness of goodness has to be taken into account if we want to better understand not only of how evil happens in the context of authority-subordinate relationships, but also how it can be prevented. To accomplish this we will first present data from a historical case involving a small community that countered the orders of powerful authorities in a wartime context. In particular, we shall examine how the community of Le Chambon resisted the systematic minority persecution implemented by the Vichy government in France (1940-1944). Then, we will compare the comportment of these French villagers with the behavior of some disobedient subjects from Milgram's experiments.

\section{Resistance to Authority in the French Village of Le Chambon (1940-1944)}

We begin by describing in some detail the historical events preceding and surrounding the rescue activities in Le Chambon. During the Nazi period in Europe, from the mid-1930s to 1944, persecuted people who were fleeing Franco's fascist regime in Spain, and later the Nazis - first in Germany and Austria and later on in Central and East Europe-found sanctuary in the French village of Le Chambon-sur-Lignon and its surrounding area known as the Plateau Vivarais-Lignon (for the sake of brevity, we shall refer to this entire region as Le Chambon). These refugees were well received in Le Chambon. They lived among the local villagers and peasants who took them in and protected them during police searches. Several accounts of this historical case have already been set forth (Dwork, 1991; Hallie, 1979; Sauvage, 1988: Zuccotti, 1993). However, by working with archives (The Magda and André Trocmé Papers recently do- 
nated to the Peace Collection at Swarthmore College Library), and with other recent testimonies and interviews (Bolle, 1992; Rochat, 1993) we have been able to collect more specific data on the unfolding confrontation between the Vichy government - working hand in hand with the Third Reich-and the people of Le Chambon. That confrontation lasted four long years, from the day of the armistice (June 22,1940) to the day of the German Army's capitulation in Paris (August 25, 1944), and can best be presented chronologically.

On June 22, 1940, when Marshal Pétain signed the armistice, he also agreed to arrest all the refugees that Hitler's government might ask for and to deport them to Germany. This agreement was widely known in Le Chambon, as it was throughout France. The day after the signing of the armistice, during a usual Sunday service, the pastors of the village, Trocmé and Theis, addressed their parishioners. A quotation from their sermon shows how they responded to Pétain's acceptance of Hitler's demands:

Tremendous pagan pressures will be put on us and our families to submit passively to a
totalitarian ideology. If they do not suceed at once in subjugating our souls. at least they
will want to subjugate our bodies. The duty of Christians is to use the weapons of the
Spirit to oppose the violence that they will try to put on our consciences. We appeal to all
our brothers in Christ to refuse to conperate with this violence. and in particular, during
the days that will follow, with the violence that will be directed at the British people.
Loving, forgiving, and doing good to our adversaries is our duty. Yet. We must do this
without giving up, and uithout being cowardly. We shall resist whenever our adversaries
demand of us obedience contrary to the orders of the Gospel. We shall do so without fear,
but also without pride and without hate. (Trocme and Theis' sermon of June 23 . 1940, The
Magda and Andre Trocme Papers. Swarthmore College library. Peace Collection).

This first act of public resistance accurately expressed the feelings of many parishioners toward the Vichy government. Most of them were descendants of Huguenots who had kept alive their own history of persecution as a religious minority, and who were well aware of the consequences of Pétain's agrecment with Hitler.

As early as 1937, the villagers had welcomed refugees from the Spanish civil war. Then in 1938, those escaping from Nazism found a safe haven in the region and, by 1940, Jewish refugees began to arrive in Le Chambon looking for a place to hide from Hitler's troops invading France. For its part, the Vichy government was quick to implement the Nuremberg laws (Zuccotti, 1993), so that immediate efforts were made to arrest foreign Jews and other refugees and place them in French internment camps. Pastor Trocmé, with the approval of his Church Council, began to search for ways to get imprisoned children out of these internment camps and bring them to Le Chambon where they could attend L'Ecole Nouvelle Cévenole, a school founded by the Trocmés a couple of years earlier, which was by now ready to assimilate the young refugees.

In the chronology of the rescue effort, the actions described above belong to a period when no actual encounters between authorities and rescuers occurred. 
Nevertheless, even in this period, the authorities' orders were quite explicit and had been widely circulated. Hence, the people of Le Chambon knew full well what the government wanted of them: To go along with the Vichy government's so-called The New Social Order, based on the three nationalistic values of "Work, Family, and Homeland." In implementing this policy, and in collaborating with Hitler's police, the Vichy government organized arrests and deportations of harmless people who were not able to hide or escape. At the same time, the government conducted an effective propaganda campaign that made reference to the great French heritage and promised a renewal of France. This propaganda included outrageous lies about the fate of the deported Jews: For example, that they would be traveling to Poland where Hitler had established a new homeland for them so that they could live together in peace. But neither the authorities' propaganda nor their orders were effective in inducing the people of Le Chambon to go along with the government's malevolent policies.

On July 16 th and 17 th, 1942, the French police arrested nearly 13,000 Jews in Paris and, shortly thereafter, deported them to German concentration camps. Less than a month later, the French Minister for Youth was sent to Le Chambon to rally young people to the Vichy government's youth organization, which was modeled after the Hitler Youth. Minister Lamirand had been informed of the Chambonnais' recalcitrant attitude toward the Vichy government, but he accepted the challenge of trying to convert them to the New Social Order. Matters did not work out as he had hoped. Immediately after delivering his speech to the assembled villagers, a group of young people approached him and requested that he immediately open and read a letter they had written protesting the roundup of the Jew's in Paris. They urged him to use his official capacity to do something about this situation. Moreover, this group informed the minister in unequivocal terms that they, themselves, intended to protect persecuted people whenever and however they could. The chagrined minister responded to this vigorous protest by alleging that his job had nothing to do with the roundup in Paris. He then turned the letter over to the prefect of police who was standing next to him. The prefect looked straight at Trocmé, who was also present, and ordered him in no uncertain terms to comply with the authorities' edicts and to turn over to the police the names of all persons who were hiding in the village. He threatened Trocmé with severe punishment should he fail to comply with these orders. Trocmé firmly refused, indicating that he could not betray those who were in need of help. Fifteen days later, police buses entered the village and officers began searching houses and farms throughout the region (Bolle, 1992). Trocmé was once again ordered to provide a list of names of hidden persons. Once more he refused to do so. For three full weeks the police searched the village and its surrounding areas. So skillfully had the refugees been hidden that in the end only 2 persons were actually arrested.

On February 13, 1943. Pastor Trocmé, Pastor Theis, and Darcissac-the 
director of Le Chambon's public school-were arrested, and shipped to a French internment camp. On February 24, 1943, the French police organized yet another raid on Le Chambon, this time managing to arrest 8 Jews. On March 15 , Trocmé, Theis, and Darcissac, who were now internees, were offered a deal: If they would sign a declaration stating that they accepted Marshal Pétain's authority, they would be free. The letter they were asked to sign read as follows:

\begin{abstract}
I the undersigned, having heen relcased from the observation camp of Saint-Paul d'Eyjcaux. Haute-Vienne, attest that the camp chief has informed me of my obligation to give my word of honor that I join the New Social Order and will show due deference to the Marshal of France, the Head of State, the man and his work. and to restrain myself from any anti-national activities, and in case I should disobcy, charges will be brought against me, and new administrative measures can be taken against me.
\end{abstract}

I declare 1 am retiring to ___. Signature ___ (Declaration of March 15, 194.3. The Magda and André Trocmé Papers. Swarthmore College Library, Peace Collection).

The pastors refused to sign that declaration, but wrote an alternative version, which read,

As a minister of religion, I cannot give my word of honor that $I$ am joining any social order. I promise to show respect for the Marshal of France, the man. (ibid.)

Without signing anything, all three were set frec the next day. Soon after their release, the camp was emptied and all prisoners deported to Germany and Poland. On June 29,1943, the German police raided a boarding school in an area adjacent to Le Chambon. This time, 19 persons were arrested, among them Daniel Trocmé - the pastor's cousin-who was later murdered in the concentration camp of Maidanek. Despite all these acts of terror and intimidation, the people of Le Chambon continued helping refugces until the very end of the war. Over the course of the Nazi era it is estimated that no less than 5000 refugees, among them 3500 Jews, found a safe haven in the village and its surrounding areas-an impressive number in contrast to the couple of dozen whom the German and French police managed to arrest.

\title{
How The Persecution of Minorities Failed in Le Chambon
}

In order to gain a better understanding of rescuers' activities in Le Chambon, we looked closely at how they responded to, and managed to counter, the officials who ordered them to comply with the Vichy government's edicts.

As suggested earlier, the most striking feature of those rescuers' actions is that they were not planned ahead of time. Almost all of those involved in the effort at Le Chambon had not plotted in advance to counter the Vichy government. Only gradually did they arrive at a path that flatly opposed the government's policies and actions regarding refugees and Jews. As the authorities put increasing pressure on them, their resistance became more determined. And as 
their involvement and commitment to helping grew, the process slowly evolved into a far more organized and complex underground operation than they could ever have anticipated. In the end they thoroughly defied authority and, in so doing. managed to save thousands of lives.

Three factors appear to have played a key role in shaping the course of their interaction with the authorities. These help us understand just how these people gradually shifted from merely conducting their daily business. to successfully preventing the Vichy government from persecuting the persons they were sheltering.

\section{Immediacy of Resistance-The Timing Chosen by the Spiritual Leaders of Le Chambon to Begin Opposing the Vichy Government}

Instead of going along - even passively - with Pétain's program for restoring France's pride and grandeur after its humiliating defeat, the pastors responded immediately to the terms of the armistice signed by Pétain, addressing in particular its implications for the persecution of refugees. Their response resonated strongly with the beliefs of many people of Le Chambon. The content of their sermon made a clear moral statement: To go along with the coming violence was unacceptable because it was anti-Christian; the villagers had to resist doing harm to others as well as preventing others from being harmed. Equally important, the timing of the sermon placed it at the very outset of the French govcrnment's collaboration with Nazi Gernnany. Compared to other cases of Church leaders who opposed the Vichy government, these pastors' sermon was decidedly an early act of resistance (Fein, 1979, chap. 4; Zuccotti, 1993, pp. 58-59). Indeed, it was the first public move against complying with the minority persecutions.

By declaring their determination to counter the harmful consequences of the Vichy government's alignment with the Third Reich the day after the armistice, the pastors were immediately challenging the authorities. As it turned out, these authorities did not initially respond to that challenge (Bolle, 1992). At first, they seemed to ignore it, allowing the pastors' challenge to go unanswered. But even without the publicity of counteractions, the pastors had firmly established a crucial precedent. The Vichy government's claim on the villagers' compliance had been weakened just as the government was beginning to implement its malevolent policies. Although Marshal Pétain-a famous commander in chief during World War I-was widely admired throughout France, Le Chambon's pastors had immediately expressed their view that Christians should not rely on Pétain's New Social Order but, instead, should look to the Gospel to make sense of the tragic French defeat and to reorient themselves more generally. Many local villagers and farmers could readily identify with their pastors' declaration of resistance. Most of them were Huguenot descendants who had kept alive their 
history of persecution as a religious minority. Trocmé himself was a Huguenot descendant, and his way of opposing the authorities was but an extension of his heritage. Once the pastors had defined the Vichy government as an accomplice to the violence initiated by Nazi Germany, the authorities' edicts became suspicious to increasing numbers of parishioners.

\section{Delay in Retaliation-The Length of Time that Passed Before the Vichy Police} Finally Searched the Village and Sought to Punish the Rebellious Rescuers

Between June 23, 1940 (the day the pastors gave their sermon), and August 26,1942 (the day the village was first raided by the police), large numbers of people in Le Chambon had become involved in helping those who came to the village to escape arrest and deportation. Thus, while the authorities hesitated in cracking down, the process of helping became an increasingly routine part of villagers' daily lives. To be sure, it was a part of their life that remained more private than public - on the surface everyone maintained the impression that they were merely attending to their normal affairs. Nonetheless, resisting authority became a standard feature of their daily life. For the most part it took the form of showing kindness toward helpless victims and, under the chilling circumstances of an ongoing persecution, kindness required defying any government edicts that threatened innocent victims. Furthermore, the authoritics' initial lack of success in getting helpers to comply with their orders proved difficult to reverse. In an important sense, the helping process developed in parallel with the persecution process. While the police were busy enforcing anti-Semitic measures in the cities-arresting foreign Jews first and French Jews soon after-the rescuers in Le Chambon were occupied with taking care of the refugees who were arriving in increasing numbers. Gradually. Le Chambon and the Plateau Vivarais-Lignon became a refuge for those escaping persecution by the Nazis and their allies. While there were a few people in the village who did not approve of what was happening, they too acquiesced to the pressures to keep silent.

Those taking part in the helping process, Trocmé, especially, were sometimes threatened with severe punishment for failing to obey official orders. However, such threats did not deter them from continuing to respond generously to requests for help so that, eventually, many people became progressively more and more involved in helping. They acted with considerable discretion, never talking openly about their deeds. The quiet and tactful nature of their activities protected them against calling the attention of officials to what was transpiring in their village. In this way the rescuers, so to speak, "allowed" the authorities to ignore what they were doing. By the time the authorities began to take active steps to retaliate, the villagers were already well prepared to hide their "guests" in the surrounding countryside. 


\section{Maintaining the Initiative-Remaining a Step Ahead of the Authorities}

A close look at the sequential order of events in Le Chambon reveals that rescuers were able to maintain the initiative in their interaction with the authorities both by countering the authorities' actions and by evading the intent of their official edicts. For instance, at the time of the Spanish Civil War, they had already begun to develop social relationships with refugees that were of a very different quality from those that would later be required of them by the Vichy government. In effect, they established an orientation of civility and kindness toward persecuted people and they proceeded to maintain this stance after it was officially outlawed by the authorities. Not only did they discreetly evade the authorities' clear intent by quietly refusing to exclude any group of people from their realm of obligation, but they actually sheltered refugees and integrated them into their schools and community, so that their "visitors" could enjoy a more or less normal social life (concerning the holding or breaking of social bonds, see Fein, 1979). As one refugee stated, "Not only were we accepted despite our differences, which is all a Jew seeks wherever he lives, but here there was a feeling of affection" (in Sauvage, 1988).

The people of Le Chambon managed also to catch the authorities off guard, and thus to remain in a position to shape the upcoming interaction. They steadily refused to accept the authorities' taken-for-granted assumptions and on several occasions even placed them in a defensive position. A prime example was confronting the Vichy minister of youth with a demand that he intervene on behalf of the Jews recently arrested in Paris. By initiating interactions on their own terms, they were a step ahead of the authorities, able to confound official efforts to enforce the government's harmful orders. By seizing the initiative. rescuers maneuvered themselves into a better position, not only morally speaking, but tactically as well. In the process of both evading and countering the Vichy government's policies against Jewish people, the villagers were building a community where Jews felt not only protected but actually welcomed. Through their tactics the Chambonnais were not only able to defy authority but also to protect refugees and build friendly relations with them successfully.

\section{The Ordinariness of Goodness}

The three factors analyzed above were facilitators of what we have called the ordinariness of goodness. The resistance in Le Chambon was the outcome of successive moves by the authorities and the rescuers, and could not have been predicted at the outset of the interaction between the Vichy government and the people of the village. In other words, as the people endorsed their pastors' declaration of resistance, they began to participate in the rescue effort, and only much later ended up successfully defying the authorities' orders. They did not 
know, as they started to help, that they would become so different from the many passive bystanders, throughout most of France, to whom they were so similar in many respects.

Interestingly, there was no overarching organization in charge of the rescue efforts in Le Chambon, although many groups and individuals contributed to it. Soon after the pastors' sermon, refugees began to arrive in the village in ever increasing numbers. Eventually, the pastors asked villagers and farmers for assistance. Even though some of them were not even their parishioners, most responded generously to the refugees. At first, helping meant giving some food, or taking people in for one or two nights. Then, as matters became worse, the helpers had to look for extra food and clothing, which was not an easy task. Fond was rationed and food stamps restricted to regular inhabitants of the community; the same was true for clothing. Hiding places also had to be secured in case of police raids. Helpers were thus confronted with all sorts of daily problems that they had to resolve. In retrospect, it seems clear that their rescue mission was really built on these day-to-day decisions having to do with very ordinary things, and that their commitment to the task was gradual.

It is also clear that, gradually, the villagers became very talented and exceedingly effective at protecting both themselves and the people they were hiding. It was a completely new experience for which they had received no prior training and which evolved through a developmental learning process. They did one thing at a time, and one thing after the other, each move bringing them closer to becoming the rescuers we admire today. At the outset they were merely decent persons helping those in need. However, these small, early steps ended up making the difference between life and death for thousands of refugees. By starting to help, the rescuers became more deeply involved in the fate of the refugees-they felt strongly pressed to learn to become effective.

\section{Resistance to Authority in Milgram's Laboratory}

The uncovering of the ordinariness of goodness in the rescue efforts of the Chambonnais lead us to reexamine the behavior of defiant subjects in Milgram's experiment-a body of data that has been largely overlooked. Is the ordinary quality of resistance found among the villagers of Le Chambon visible also among Milgram's subjects? If the banality of evil can be seen clearly in Milgram's experiment, is it possible also to see the ordinariness of goodness? Although there are many differences between what happened in Le Chambon and what transpired in Milgram's laboratory, both the Chambonnais and the subjects in Milgram's studies were caught between the pleas of helpless victims and the orders of malevolent authorities.

Before examining closely the transcripts of some of Milgram's disobedient subjects, we note that the three factors that facilitated effective resistance in Le 
Chambon also operated to enhance successful resistance in Milgram's experiments. The role of immediacy of resistance is discussed at some length in our other article in this issue (Modigliani \& Rochat, this issue). There, it is shown that subjects who began questioning or objecting to the experimenter's requests early in the procedure were substantially more likely to end up becoming defiant. The role of length of waiting period can only be speculated about with respect to Milgram's work, as he did not allow his subjects any meaningful waiting time. Indeed, the rapid pace at which prods and orders follow upon one another, in all his conditions, is one of the most salient and compelling features of his experimental design. It is quite reasonable to speculate that, if subjects had been given a few minutes to gather their thoughts-say, one third of the way through the procedure (after 150 volts) or even halfway through (after 225 volts) - many more of them would have been able to formulate a line of argument that could have permitted them to break off the experiment. For the present, however, this remains an untested hypothesis. The role of maintaining the initiative is closely intertwined, in the Milgram experiments, with immediacy of resistance. As discussed in our companion article in this issue, many subjects were able to seize the initiative, and catch the experimenter off guard, by rather quickly posing questions and/or objections that the experimenter was not able to respond to effectively using the rather limited set of prods at his disposal. The authority's seeming evasiveness and unresponsiveness appeared to contribute notably to subjects' ability to persist and eventually become fully defiant. Beyond these facilitating factors that appear to be at work in both settings, it is also true that some of Milgram's disobedient subjects verbalized their resistance in ways reminiscent of rescuers in Le Chambon.

Before examining some of these responses, it is important to emphasize that our conception of the ordinariness of goodness is not intended to imply that goodness is commonplace so that it will be readily observable in encounters between authorities and subordinates. Rather, it is meant to suggest that goodness-where and when it does happen to exist-can be expressed in quite ordinary ways that are mere extensions of common civility or basic decency. This is not to deny that goodness can also be expressed in ways that are far more dramatic, courageous, or heroic. Just as André Trocmé's valiant confrontations with chiefs of police and internment camp officials cannot be construed as mere acts of common decency, so it should be no surprise that some of Milgram's disobedient subjects expressed their resistance in a manner somewhat closer to the heroic mode. In particular, some took stands that conveyed an uncompromising independence and a disparaging orientation toward the experimenter. Interestingly, two of these subjects are prominently featured in Milgram's (1965) film Obedience.

For example, consider the following firmly resolute, even rebellious, subject who broke off at 150 volts, just after the victim made his first serious protest: 
(E): Continue please, teacher. Go on, the next word is "sad."

(S): I'm not going to go on if he refuses to do it.

(E): The experimenter requires that you go on, teacher.

(S): If he refuses? . . I won't!

(E): Whether the learner likes it or not, we must go on until he's learned all the word pairs correctly.

(S): Well, he don't want to. I refuse to:

We would argue that this interaction sequence is not typical - that just as many, if not more, subjects who end up defiant follow a path more consistent with the ordinariness of goodness.

For example, the following subject, who broke off at 195 volts, reacted in a notably meeker and more polite manner:

(S): (After delivering 195 volts.) Do you think we better continue? I hear him yelling.

(E): The experiment requires you to go on. Please continuc.

(S): Yeah, but it's not fair.

(E): Whether the learner likes it or not, we must go on until he's learned all the word pairs correctly.

(S): Yeah, but he's in pain, Sir. It's going against his will. I mean, I don't wish to tell you how to run your experiment but aaahh. .

(E): Continue, teacher. The next word is "red."

(S): (Reads the next word pairs, which the victim gets wrong, and prepares to deliver 210 volts) The next shock is . . Sir, I can't do this I'm sorry.

(E): The experiment requires you to go on, teacher.

(S): Yeah, but 1 can't.

(E): It's absolutely essential that you continue.

(S): Well, ... to me . . . well, whether I'm a weakling or what, I just can't, Sir.

Here the interaction unfolds in such a way that the subject expresses little belligerence or bravado, simply a decent concern for the injustice of continuing to inflict pain on a helpless victim.

According to Milgram (1974), in the course of his experiments, he encountered only two subjects who refused outright to administer a single electric shock. Both of them participated in Experiment 10 (office building in Bridgeport) and both of them refused to participate for fairly ordinary reasons in a nondramatic fashion. One of them declined to sign the release form he was required to fill out at the beginning of the experiment, on the grounds that he did not know enough about the nature of the research. The release form stated:

In participating in this experimental research of my own free will, I release the Research Associates of Bridgeport and its employees from any legal claims arising from my participation.

Signature __ (Subject File No. 2332, The Milgram Papers, Yale University Library)

Several months later, while answering the questionnaire that Milgram sent to all the participants in his experiment, this subject added the following comment:

1 am appalled to think that, of the hundreds of persons who participated in your experiment, I was the only one who refused to sign the waiver without knowing what the testing would entail. (ibid.) 
The second subject who refused to give any shocks whatsoever watched, somewhat uneasily, as the victim was being strapped into his "electric chair," then indicated that he did not wish to participate because he did not want to be sued in case something happened to the learner. In a side comment on his questionnaire, he wrote,

I was not too concemed abuut the experiment until I related it to a lawsuit filed against myself, due to a fall on my sidewalk, when the fault was actually due to negligence on the part of the other person. (Subject File No. 2314, ibid.)

In neither of these cases is it entirely clear that the subjects were acting out of goodness. Indeed, on the surface, both seemed to be more concerned with the egotistical issue of avoiding potential lawsuits (cf. Meeus \& Raaijmakers, this issue). Yet, it is difficult to judge the extent to which such legalistic excuses were merely a polite cover for deeper humanitarian concerns. The second subject appeared to have no qualms until he saw the victim being strapped down. Certainly, both of these subjects managed to exit the situation in a discrete, civil, and nonconfrontational manner. It should be remembered that many actions taken by the people of Le Chambon were designed to smooth their surface relations with authority, thereby sparing themselves possible retribution, as well as protecting the people they were rescuing.

Returning, now, to disobedient subjects who refused to go on while in the process of giving the electric shocks, we found that they too opposed the experimenter's orders in ways suggestive of ordinary goodness. There were three main themes in their replies to the experimenter's prods.

1. One should not impose one's will on another. This was the main reason given by disobedient subjects for not completing their task. For example, one subject said to the experimenter, "I'm not going to go against his will. If he doesn't want to do it 1 won't. It's not going to be a oneway street. I'm not going on unless he's willing to go on. If he won't go on, I'll to go along with him." Another subject declared, "I don't think it would be fair to this man to force him to do something he doesn't want to. It's up to him to make his own decisions."

2. One is responsible for what one does to another. This theme was used less frequently than the first one, but it was invoked by several subjects when the experimenter kept insisting that they continue with the experiment. One subject said, "Is this part of the contract? I'm not gonna' continue unless he's willing to go along with the experiment. Legally I'm responsible for pushing his hand down. I'm the one responsible and I can be sued as well as you can."

3. One is always free to choose not to obey harmful demands. This theme was most commonly invoked at that point in the experimental procedure when resistant subjects are flatly told that they "have no other choice" 
but to continue. This assertion can elicit strong reactance. One subject replied, "My choice is that I just walk right out of here. I can walk out any time I feel like getting out." Another subject snapped, "I have no other choice? Are you kidding, Sir? You want me to keep administering shocks to this gentleman? I'm a human being. Gee, what if the situation was reversed."

These subjects' responses to the experimenter's prods suggest that many disobedient subjects are ones who manage to articulate one or more fairly ordinary rules about interpersonal relations: don't impose your will on others; take responsibility for your actions; feel free to refuse injurious instructions. By invoking or referring to such rules, they oppose the experimenter in an ordinary, civil manner, without having to challenge him directly, or criticize or castigate him. For the most part, reminiscent of Collins and Brief's (this issue) positively evaluated Polite Disobedience, they patiently counterargue his demands so that the ongoing harm can be stopped and the victim spared.

It is not easy to expound on the ordinariness of goodness based on limited transcripts of the responses of Milgram's disobedient subjects. But if their resistant behavior was, indeed, as nonconfrontational and as rooted in common-sense ethical rules as it appears to be from the material we have been able to review, there is a real possibility that developing a dialectic between the banality of evil and the ordinariness of goodness can lead to a richer understanding of authoritysubordinate relations.

\section{References}

Arend1, H. (1963). Eichmann in Jerusalem: A report on the banaliry of evil. New York: Viking Press. Bauman, Z. (1991). Modernity and the Holocaust. Ithaca, NY: Comell University Press.

Blass, T. (1993). Psychological perspectives on the perpetrators of the Holocaust: The role of situational pressures, personal dispositions, and their interactions. Holocaust and Genocide Studies. 7, 30-50.

Block, G., \& Drucker. M. (1992). Rescuers: Portruits of moral courage in the Holccaust. New York: Holmes \& Meier.

Bolle, P. (Ed.). (1992). Le Plateau Vivarais-Lignon: Accueil et nésistance, 1939-1944 [The Plateau Vivarais-Lignon: Hospitality and resistance, 1939-1944]. Le Chambon-sur-Lignon: Société d'Histoire de la Montagne.

Browning, C. (1992). Ordinary men: Reserve Police Battalion 101 and the Final Solution in Poland. New York: HarperCollins.

Darley. J. (1992). Social organization for the production of evil. Psychological Inquiry, 3, 199218.

Dwork, D. (1991). Children with a star: Jewish youth in Nazi Europe. New Haven, CT: Yale University Press.

Fein, H. (1979). Accounting for genocide: National responses and Jewish victimization during the Holocaust. Chicago: The University of Chicago Press.

Fugelman, E. (1987). The rescuers: A sociopsychological study of altruistic behavior during the Nazi era. Ann Atbor: University Microfilms International.

Fogelman, E. (1994). Conscience and courage: Rescuers of Jews during the Holocaust. New York: Anchor Books. 
Gushee, D. P. (1993). Many paths to righteousness: An assessment of research on why righteous Gentiles helped Jews. Holocaust and Genocide Sudies. 7, 372-401.

Hallie. P. (1979). Lest innocen blood he shed: The story of the village of Le Chambon and how goodress happened there. New York: Harper \& Row:

Humer, E. (1994). Gehorsam und Verweigerung: Die Geschichte eines Experiments [Obedience and refusal: The story of an experineme] [Film|. (Available from Prisma Film. Vienna).

Kanz, F. 1993$)$ Ordinary people und extraordinary evil: A report on the he guilings of evil. Albany: State Liniversity of New York Press.

Keller. S. (1993). Grïningers Fall: Geschichten von Flucht und Hilfe Gruninger's case: Stories of flight and rescuel. Zürich: Rotpunktverlag.

Milgram. S. (1965). Obedience. [film]. (Availabie from New York Lniversily Film Library.)

Milgram. S. (1974). Obedicnce to authority: An experimental view. Vew York: Harper \& Row.

Oliner, S., \& Oliner, P. (1988) The altruistic personaliz: Rescuers of Jews in Nazi Europe. New York: The Free Press.

Rochat, F. (1993). Intervies with Nelly Trocunc. Lnpublished transcript, the Lniversity of Michigan. Sauvage, P. (1988). Weapons of the spirit. (Film). (Available from Friends of Le Chambon, Los Angeles.)

Stein. A. (1988). Quier heroes: True stories of the rescue of Jous by Christians in Nazi-occupied Holland. New York: New York University Press.

Tec. $N$. (1986). When ligh pierce the darkness: Christian rescuc of Jews in Nazi-occupied Poland. New York: Oxford University Press.

Zuctotti. S. (1993). The Holocaust, the French, and the Jew's. New York: Basic Books.

FRANÇOIS ROCHAT is a research psychologist in the Department of Psychology at The Lniversity of Michigan. He received his Ph.D. in psychology from the Universit de Lausanne, Switzerland. His recent work has focused on authoritysubordinate relationships - in particular. on the social psychological dynamics of resistance to authority in experimental settings, as well as in a variety of historical contexts.

ANDRE MODIGLIANI received his Ph. D. in social psychology from the "old" joint program in sociology and psychology at the Lniversity of Michigan. He is an associate professor of sociology at the Lniversity of Michigan, Ann Arbor. With William Gamson he has done two books: Untangling the Cold War: A Strategy for Testing Rival Theories and Conceptions of Social Life: A Text-Reader for Social Psychology. His recent work has dealt with media discourse on political issues and its relationship to public opinion. Currently, he is pursuing work on obedience and defiance to authority in both historical and laboratory contexts. 
Copyright of Journal of Social Issues is the property of Blackwell Publishing Limited and its content may not be copied or emailed to multiple sites or posted to a listserv without the copyright holder's express written permission. However, users may print, download, or email articles for individual use. 